\title{
Retraction Note: Ferroportin in the progression and prognosis of hepatocellular carcinoma
}

Qin Wang ${ }^{1}$, Jun Zhou ${ }^{2 *}$, Dewu Zhong ${ }^{3}$, Qunwei Wang ${ }^{2}$ and Jiangsheng Huang ${ }^{2}$

\section{Retraction}

The Publisher and Editor regretfully retract this article [1] because the peer-review process was inappropriately influenced and compromised. As a result, the scientific integrity of the article cannot be guaranteed. A systematic and detailed investigation suggests that a third party was involved in supplying fabricated details of potential peer reviewers for a large number of manuscripts submitted to different journals. In accordance with recommendations from COPE we have retracted all affected published articles, including this one. It was not possible to determine beyond doubt that the authors of this particular article were aware of any third party attempts to manipulate peer review of their manuscript.

\footnotetext{
Author details

'Department of Gynecology, The Second Xiangya Hospital of Central South University, Changsha 410011, Hunan Province, China. ${ }^{2}$ Department of

Minimal Invasive surgery, The Second Xiangya Hospital of Central South University, 139 Renmin Middle Road, Changsha 410011, Hunan Province,

China. ${ }^{3}$ Department of General Surgery, The Second Xiangya Hospital of

Central South UniversityChangsha, Changsha 410011, Hunan Province, China.
}

Received: 25 January 2015 Accepted: 3 March 2015

Published online: 26 March 2015

\section{Reference}

1. Wang $Q$, Zhou J, Zhong D, Wang Q, Huang J. Ferroportin in the progression and prognosis of hepatocellular carcinoma. Eur J Med Res. 2013;18:59.

\footnotetext{
* Correspondence: zhoujun0006@126.com

${ }^{2}$ Department of Minimal Invasive surgery, The Second Xiangya Hospital of Central South University, 139 Renmin Middle Road, Changsha 410011, Hunan Province, China

Full list of author information is available at the end of the article
}

\author{
Submit your next manuscript to BioMed Central \\ and take full advantage of: \\ - Convenient online submission \\ - Thorough peer review \\ - No space constraints or color figure charges \\ - Immediate publication on acceptance \\ - Inclusion in PubMed, CAS, Scopus and Google Scholar \\ - Research which is freely available for redistribution
}

Submit your manuscript at

www.biomedcentral.com/submit

() Biomed Central

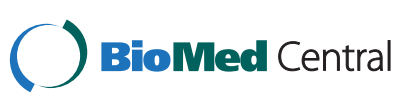

